\title{
A Campus Fesztivál gazdasági hatásmérése, eredményességének vizsgálata az elmúlt 10 esztendő alapján
}

\author{
R. Zs. PAP \\ University of Debrecen, rekupap@gmail.com
}

Absztrakt. Évszázadok óta a különféle rendezvények, föként a fesztiválok fontos szerepet töltenek be a társadalom életében. Számos kutatás, tanulmány született már korábban, amelyek a magyarországi és külföldi fesztiválokat elemezték gazdasági, társadalmi és kulturális szempontból. A vizsgálatok elkészítésének alapvető problémája, hogy központilag nincsen vagy kevés adat áll rendelkezésre gazdasági hatásvizsgálatok elkészítéséhez. A kutatásom célja a meglévő adatok alapján egy átfogó gazdasági hatásmérés elkészítése a debreceni Campus Fesztiválról.

\section{Bevezetés}

A fesztiváloknak nincs általánosnak vett, nemzetközileg elfogadott definíciója. Ezek a rendezvények a civilizációk fejlődését végigkísérve mindig meghatározó szereppel rendelkeztek, mivel a kultúra egy olyan területét képviselik, amely az ember jólléti igényeit kielégítve teret enged bizonyos jeles események megünneplésére [3]. A globalizáció kiterjedésével rohamosan nőtt ezen események száma, a 21. századra a fesztiválok a legpiacképesebb kulturális és turisztikai termékek közé tartoznak. A rendezvények a nagyközönséget megmozgató, az életminőséget határozottan javító közösségi intézményekké váltak. A fesztiválok mára szerteágazó, össztársadalmi üggyé és világméretű turisztikai jelenséggé alakult át [1].

\section{A fesztiválok gazdasági hatásainak jellemzői}

A fesztiváloknak lehet társadalmi, kulturális, fizikai, környezeti, politikai és gazdasági hatásai is, melyek egyaránt lehetnek pozitívak és negatívak Pozitív hatások közé tartozik az, hogy az értékesítés növekszik, a helyi termékek és szolgáltatások hozzáadott értéke emelkedik, ezáltal a helyi lakosok bevétele is emelkedik. Negatív hatások közé sorolhatjuk az árszínvonal emelkedését, melyet a megnövekedett turisták száma idéz elő. A gazdasági hatások általánosítása nem lehetséges, hiszen számtalan eseményt különböztetünk meg, s ezek nem csak témájukban különböznek, de a kiállítók és résztvevők is különbözőek. A gazdasági hatások alatt a fesztivál megrendezéséből származó bevételeket, a foglalkoztatottságra gyakorolt hatásokat, és az esemény kapcsán megvalósuló beruházásokat szokás vizsgálni. A fesztivál gazdasági hatása egy régió makrogazdasági helyzetére 
elsődleges és másodlagos gazdasági impresszióval is bírhat. Elsődlegesek közé az esemény közvetlen hatásait soroljuk. Összességében azokat a bevételeket soroljuk ide, melyek a fesztivállátogatók igényeinek kielégítésére szolgálnak. A közvetett hatások, az úgynevezett új pénz beáramlásából származnak, a közvetlen az, ami közvetett költést generál. Az indukált hatásokat egy olyan megnövekedett gazdasági aktivitás, mely a szolgáltatóktól vagy azok alkalmazottainak megnövekedett béreiből származik, tehát a közvetlen és közvetett hatások eredményezik.

\section{A kutatás módszertana}

A gazdasági hatások mérésére nemzetközi viszonylatban számtalan lehetőség létezik, ezek azonban nagyrészt itthon - a legyűjtött adatok hiánya miatt - nem használhatók [2]. A begyưjtött adatok és információk mennyisége befolyásolja egy hatásmérés pontosságának a mértékét. Minél szélesebb körből származnak az adatok, annál szerteágazóbb, és részletesebb kimutatások hozhatóak létre. Mivel hazánkban erősen korlátozottan állnak rendelkezésünkre statisztikai lekérdezések, melyek szükségesek lennének egy-egy fesztivál komolyabb gazdasági hatásméréséhez, így nagyban megnehezített helyzetben kezdünk el a már meglévő adatokból kiszámolni gazdasági eredményeket. A kutatásomhoz a szervezők által biztosított Szinapszis felméréséket illetve saját kérdőívem által gyüjtött információkat használtam fel.

\section{Regressziószámítás}

Az általam mért eredmények és a szervezet által kiadott adatok alapján két számítási lehetőséget tartottam fontosnak megvizsgálni. Az egyik, hogy milyen összefüggés található a látogatók száma és a fellépőkre kiadott összegek között. A másik számítás folyamán arra próbáltam bizonyítékot találni, hogy van-e összefüggés az átlagköltség és a fellépőkre kiadott kiadások között. Ezeknek az összefüggéseknek a vizsgálatára a legjobb mérési módszernek a regresszió számítást gondoltam. regresszió voltaképp a statisztikában jól bevált számítási eljárás. Lényege, hogy két különböző változó, vagy több változó közötti összefüggést, a kapcsolatukat vizsgálja. Ezt egy függvény alkalmazásával jól reprezentálhatóvá alakíthatjuk, amellyel sokkal hatásosabban bemutathatjuk a kapott eredményeket.

Ahhoz, hogy bebizonyíthassuk, hogy van összefüggés a látogatói számok illetve a fellépőkre kiadott pénzmennyiség között, egy Excel adatelemzési lehetőséget alkalmaztam és igyekeztem regressziós becslést végrehajtani. 


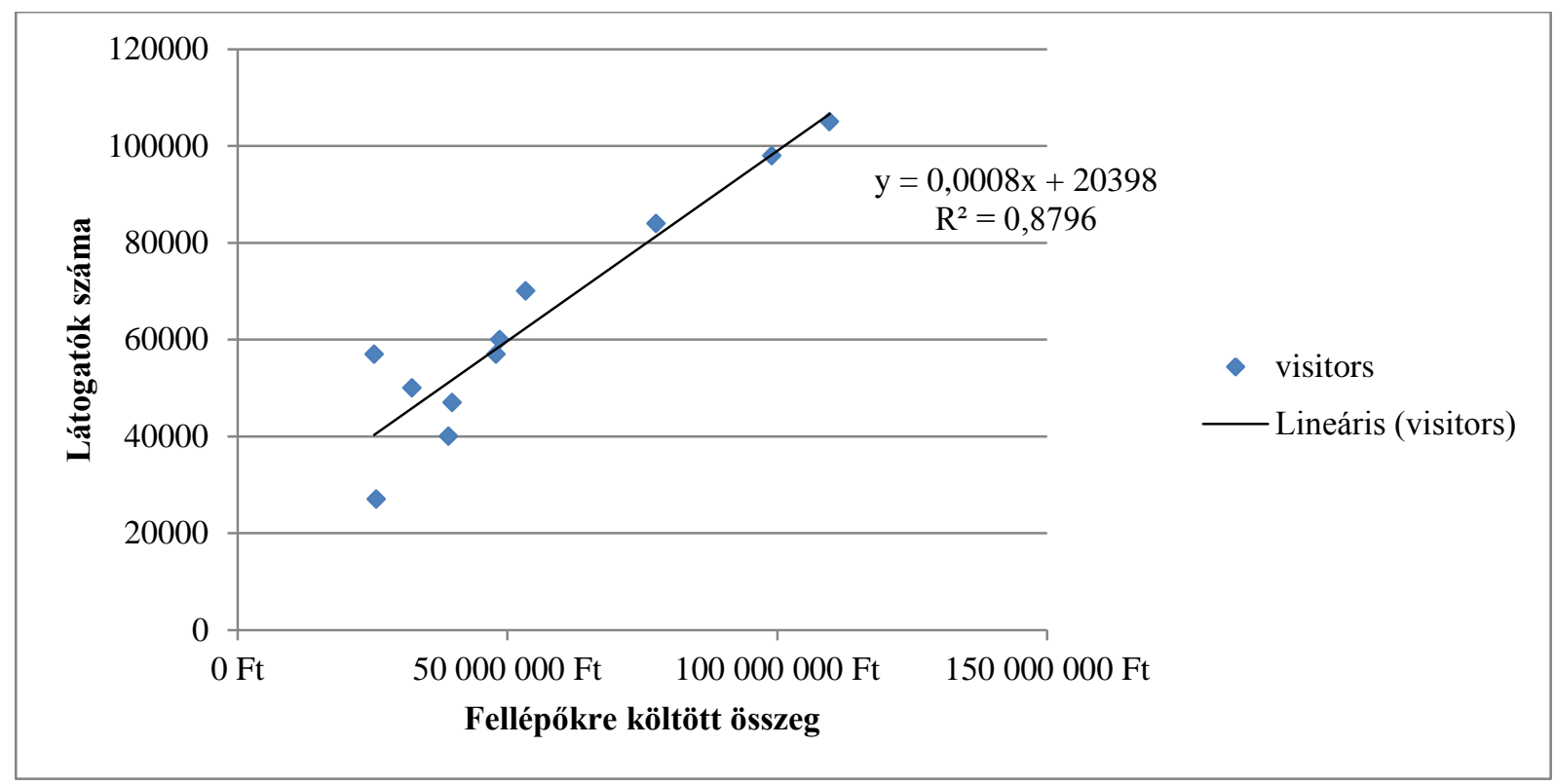

1. ábra: Fellépőkre költött összeg a látogatói szám alapján történő becslése 2007-2017-ig (Forrás: Saját számítás)

Az ábrán (1. ábra) látható a Campus Fesztivál éves szinten fellépőkre költött összegének becslése, valamint a regresszió számítással becsült függvénye. Jól látható, hogy a becsült függvény igen jól illeszkedik az eredeti adatsorhoz, csupán néhány érték van, amely kiugrik a lineáris függvényből. A legjobb illeszkedést a lineáris regresszióra kaptam, részben tekintettel arra, hogy az R2 értéke 0,8796, az R értéke pedig 0,94. Ugyanebben az esetben a 95\%-os megbízhatósági szinthez tartozó konfidencia intervallum alsó értéke: 9,4917, a felső értéke: 9,6268, amiből jól látható, hogy az értékek nem nagy intervallumban mozognak, következtetésképpen az eredmények jó közelítésnek tekinthetőek az eredeti adatokhoz.

Mindez azt jelenti, hogy ha hipotézisvizsgálatot végzünk a magyarázó változó együtthatójára a t teszt (statisztika) segítségével, azaz:

$$
\begin{aligned}
& H_{0}: \beta_{1}=0 \\
& H_{0}: \beta_{1} \neq 0,
\end{aligned}
$$

Akkor 5\%-os szignifikancia szinten, azaz 95\%-os megbízhatósági szinten elvetjük a null hipotézist. Mindez azt jelenti, hogy a felállított modellben a független változónak statisztikailag szignifikáns magyarázóereje van a függő változóra.

A becslés alapján megkaphatjuk a 2017-es becsült adatot a fellépőkre költött összegre nézve, és így bevezethetünk egy új rugalmassági együtthatót, a látogatók számának (mint keresletnek) a fellépőkre költött összeg szerinti rugalmassági együtthatóját. A kiindulási képlet:

$$
\varepsilon_{x, y}=\frac{d Q}{Q}: \frac{d V C}{V C}=\frac{d Q}{Q} \times \frac{V C}{d V C}=\frac{d Q}{d V C} \times \frac{V C}{Q}
$$


Ahol $Q$ a fesztiválra látogatók számát, és $V C$ a fellépőkre költött összeg nagyságát jelenti.

$$
\varepsilon=\frac{d Q}{d V C} \times \frac{V C}{Q}=0,000786 \times \frac{109694082,2}{105000}=0,5747
$$

Amiből arra következtethetünk, hogy ha 10\%-kal növekedik a fellépőkre fordított összeg, 5,747\%-kal fog növekedni a látogatók száma. A lineáris regressziós függvény egyenlete alapján megállapíthatjuk, hogy ha 1 millió forinttal növeljük a 2017. évben a fellépőkre kiadott összeg mértékét, akkor a becslések alapján a látogatók száma 800 fővel emelkedik.

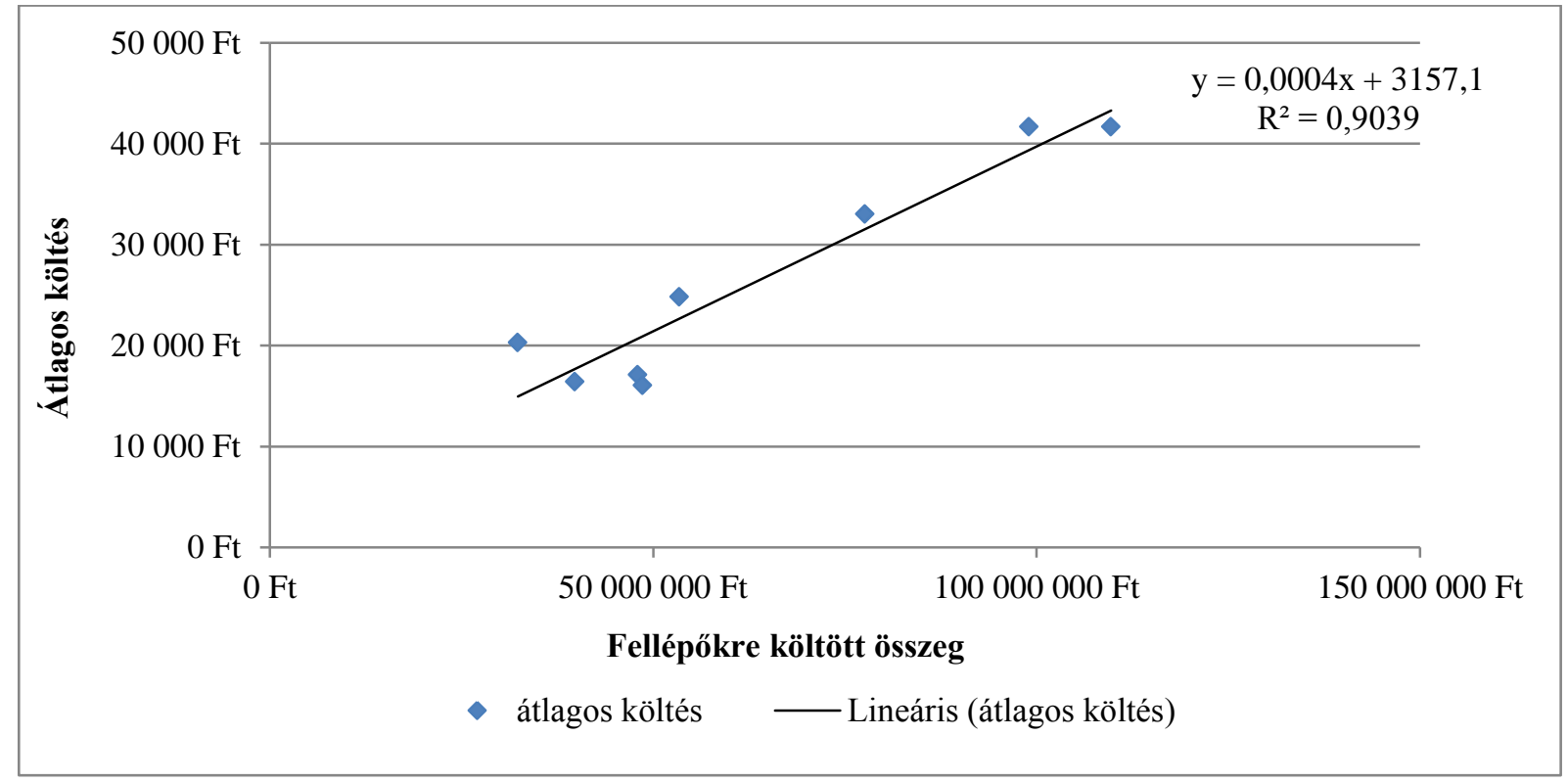

2. ábra: Fellépőkre költött összeg az átlag költés alapján történő becslés 2007- 2017-ig (Forrás: Saját számítás)

Az 2. ábrán látható a Campus fesztivál fellépőkre költött összegének (2007-2016. év) adatai és fesztiválon történő átlagköltések adatai A legjobb becslésű regressziót a lineáris regressziós modell adta, részben tekintettel arra, hogy az R2 értéke 0,9039, az R értéke pedig 0,95. Ugyanebben az esetben a konfidencia sáv alsó értéke: 9,4917, a felső értéke: 9,6268, amiből jól látható, hogy az értékek nem nagy intervallumban mozognak, következtetésképpen az eredmények jó közelítésnek tekinthetőek az eredeti adatokhoz, valamint a konfidencia intervallum ebben az esetben sem tartalmazza a zérus értéket (95\%-os megbízhatósági szinten). A becslés alapján megkaphatjuk a 2017es körülbelüli adatot a fellépőkre költésére nézve és így kiszámolhatjuk az egy látogatóra becsült kiadás rugalmassági együtthatójának a mértékét a fellépőkre költött összegre nézve. A kiindulási képlet itt is ugyanaz:

$$
\varepsilon_{x, y}=\frac{d A C_{1}}{A C_{1}}: \frac{d V C}{V C}=\frac{d A C_{1}}{A C_{1}} \times \frac{V C}{d V C}=\frac{d A C_{1}}{d V C} \times \frac{V C}{A C_{1}},
$$


ahol $A C_{1}$ azt mutatja, hogy mennyit költött a fesztivál ideje alatt 1 látogató, $V C$ a fellépőkre költött összeg nagyságát jelenti

$$
\varepsilon=\frac{d A C_{1}}{d V C} \times \frac{V C}{A C_{1}}=0,0004 \cdot \frac{109694082,2}{41687}=0,1052
$$

A rugalmassági együttható alapján megállapíthatjuk, hogy ha 10\%-kal emelkedik a 2017. évben fellépőkre költött összeg nagysága, akkor az egy látógatóra eső kiadás mértéke a becslések alapján 1,052\%-kal emelkedik. Ezekből a számításokból arra következtethetünk, hogy van kapcsolat az értékek között, a fesztivál minőségre számít, azaz hatással van a látogatók költési hajlandóságára.

\section{4. Összegzés}

A dolgozatom megírása előtt az alapvető célom az volt, hogy egy már meglévő gazdasági hatásmérés példáján keresztül vizsgáljam meg a debreceni Campus Fesztivál elmúlt 10 éves teljesítményét. A dolgozat megírása közben magam is tapasztaltam, hogy a KSH adathiánya miatt igen kis mértékben állnak rendelkezésre a vonatkozó adatok. Így egy olyan eljárást alkalmaztam, amely különböző változó, vagy több változó közötti összefüggést méri. Az általam mért eredmények és a Debreceni Campus Nonprofit Közhasznú Kft. által biztosított adatok alapján két számítási lehetőséget tartottam fontosnak megvizsgálni. Az egyik az az összefüggés, amely a látogatók száma és a fellépőkre kiadott összegek között van. A másik számítás során arra próbáltam bizonyítékot találni, hogy van-e összefüggés az átlagköltség és a fellépőkre kiadott kiadások között. A vizsgálataim eredményesnek bizonyultak, igazolást nyert, hogy befolyásoló hatással bír egy rangosabb előadói kör kialakítása.

\section{Hivatkozások}

[1] Getz, D. (1991) Festivals, Special Events, and Tourism. Van Nostrand Reinhold, New York.

[2] Kundi, V. (2013) Fesztiválok városokra gyakorolt gazdasági és társadalmi kulturális hatásainak elemzése. Doktori értekezés, Győr.

[3] Jászberényi M., Zátori A., Ásványi K. (2016) Fesztiválturizmus. Akadémiai Kiadó, Budapest. 